\title{
Assessment of the nutritional status and the prevalence of obesity in the primary school children belong to different socio-economic status
}

\author{
Halime Pulat Demir, Kubilay Karşıdağ \\ İstanbul Gelisim University School of Health Sciences Department of Nutrition and Dietetics \\ İstanbul University Faculty of Medicine, Department of Internal Medicine, Endocrinology and \\ Metabolism Diseases Department
}

\section{Email address:}

hpulatdemir@qelisim.edu.tr (Halime Pulat Demir, Kubilay Karşıdağ )

\section{To cite this article:}

Halime Pulat Demir, Kubilay Karşıdağ. Assessment of the nutritional status and the prevalence of obesity in the primary school children belong to different socio-economic status. Journal of research in health science. Vol. 2, No. 2, 2017, pp. 30-40. DOI 10.26739/2523-1243

\section{doij http://dx.doi.org/10.26739/2523-1243/-2017-2-2-6}

\begin{abstract}
Purpose: The aim of this study, to evaluate the eating habits and physical activities and to determine the prevalence of obesity of primary school-aged children belong different socio-economic classes.

Method: The study was carried out on 621 children who are in the 7-15 age group in two elementary school that is in the different socio-economic status at the province of ?stanbul. As a data collection tool, a questionnaire which examines the demographics characteristics, nutrition and physical activity of children was performed.Anthropometric measurements of students (height, weight, waist and hip circumference), BMI (body mass index) and waist/hip ratio were calculated.The reference values of Turkish children is used for determining the obesity rate.

Results: At the end of the study, It was determined as the overweight prevalence of students is $11.9 \%$, the obesity prevalence is $11.8 \%$. Overweight and obesity prevalence was found respectively in a private school as $17.3 \%$ and $15.3 \%$, in a public school as $8.8 \%$ and $6.6 \%(\mathrm{p}<0,05)$. Regarding the relationship between BMI and waist circumference, BMI and hip circumference was found astrong correlation (respectively $r=0,852$ and $r=0.865$ ). Students' the way of going to school was found to be an important factor on obesity in logistic regression analysis.

Conclusion Having a greater percentage of obesity observation in the school that its socioeconomic status is high makes us think that environmental factors is more effective than genetic factors in the development of obesity in our society.
\end{abstract}

We recommend taking the necessary precautions on this issue which concerns the public health.

Keywords: Keywords: socio-economic status, primary school children, obesity, BMI, nutrition. 
NOTE: Istanbul University Institute of Health Sciences, Department of internal medicine produced from doctoral thesis titled "The assessment of Nutrition Habits, Physical Activity and Obesity Prevalence in Primary School Children from different Socioeconomic Status." was prepared in 2011.

\section{INTRODUCTION}

Obesity (overweight) is a fat mass in the body and it is an increasement of the amount of fat by disordering the ratio of lean mass, and because of that, the body weight rise above the level that is required according to height $(1,2,3)$. The prevalence of obesity is increased steadily in recent years, and it is recognized as a problem of epidemic in the worldwide especially in developed countries and now it is considered as a disease $(4,5)$. The prevalence of obesity is increasing in all age groups today. It has been reported that $42-63 \%$ of children who are obese in the school-age have also to be obese in the time when they are adults and because of the risk period that is began very early in their life, their probability of meeting with important health issues is higher in early adulthood (4).

Obesity, sedentary life is a major growing problem which is depending on social, psychological and environmental factors improper nutrition applications (6). Today, with the development of technology and changing of the social structure, children are spending their leisure time on the TV and $\mathrm{PC}$, not playing on the garden or on the street, and this leads to increase obesity progressively (7).

Obesity is a term which is used to express the excess fat in the body and it is a major public health problem which is affecting human health $(8,9)$. Because of the fact that between obesity and the many diseases such as hypertension, cardiovascular disease, diabetes, degenerative arthritis, thrombophlebitis have a significant relationship, Persons who is overweight in childhood wait more mortality and morbidity in adulthood. The health problems that arised in the long term of the childhood obesity will bring heavy loads to the health system. For this reason, prevention and treatment of childhood obesity become more importance. Obesity in childhood is quite difficult to the treatment when it continues in adulthood. To prevent the occurrence of obesity instead of treating obesity after it is formed is a more effective and more convenient way $(10,11)$. Today, cause of obesity increase is that children spend more time on TV and PC moving away from physical activity and the consumption of extremely fats and carbohydrates than normal. In childhood obesity; food advertising, new types of food and drinks offered in marketing, spanning fast-foodstyle diet (fast food diet), chocolate candies, gas-sweetened beverages are also very effective $(12,13)$.

Our country contains both developed countries and developing countries problems from the point of nutritional status. The nutritional status of people in Turkey shows significant differences according to regions, seasons, socio-economic status and urban and rural areas. Imbalance in the income distribution is one of the main causes of this. This situation is effective for the occurrence of nutrition problems such as obesity and its prevalence (12).

This study, nutritional habits of students and evaluation of physical activity and determining prevalence of obesity are aimed with a cross-section taken from children who are in primary school age at the different socio-economic levels. 
Halime Pulat Demir, Kubilay Karşıdağ . Assessment of the nutritional status and the prevalence of obesity in the primary school children belong to different socio-economic status

\section{MATERIAL AND METHOD}

A number of students who continue in a state school dependent on the Ministry of Education in ?stanbul Bah?elievler district and all students who continue in a private primary school dependent on the Ministry of Education in ?stanbul Bak?rk?y district were included in our study. Necessary permits from the relevant school principals for study and Ethics Committee approval from Istanbul University Faculty of Medicine has been received.

A questionnaire will be used in the study, parental permission form, informed consent form are sent to all parents in these schools, and their written permission was obtained.

Parents of children who refuse to partici pate in the study are excluded from the study.

All students (301) of 7-15 age group who are studying and learning in the private school between 1 February-1 April 2010 and 1 branch randomly selected from each class (320) from students of 7-15 age group who are studying and learning in state schools were included in the study. Students who were not in the school for any reason in specified dates, who have a chronic disease or orthopedic defects were excluded from the study.

The questionnaire form which is developed in accordance with the relevant literature is used as the data collection tool. The survey questions are formed with the family's socio-economic status, student meal scheme and nutritional habit, the frequency of food consumption, the time spending on the TV or PC and the questions related to physical activity. Information's are given about the questions by going to each class and surveys have been completed in the classroom.
Anthropometric measurements of the students (height, weight, waist circumference, hip circumference) were taken in the school infirmary. Stadiometre is used in measuring students' lengths with bare feet and bare-head, head in Frankfort plane (eye triangle and upperpart of the auricle aligned, parallel to the ground), rear of the head, back and heels on a straight wall, at straight-and-standing position, from top of the head to the sole. Weight is measured by a digital balance sensitive to 100 grams on a plain surface, the scale is zeroed, heavy clothing such as jacket etc., are taken off, only their school uniform remaining, and with bare feet and calibration is checked after every weighing. Waist circumference is measured from between the middle point between lowest-costa bone and belly button, hips are measured from one side of the children, from the side of larger trochanters and by a nonelastic tape-measure.Waist/hip ratio were calculated. In Hati po?lu et.al. study; performed in Kayseri on 699 schools and 4770 students of 7-17 age; percentile figures for Turkish children and adolescents have been determined (14). In our study; waist circumference of the children have been evaluated taking basis in this study. By using the weight and length data; body-mass indices (BMI) of every student is calculated as weight $(\mathrm{kg}) /$ length2 $(\mathrm{m} 2)$. Lissau et.al. study has shown contradiction in BMI figures of 15 countries with BMI above $85-95 \%$. Accordingly they pointed out that each country should use its own BMI reference figures (15). In our country, Bundak et.al. in 2006 in ?stanbul have determined the weight, height and BMI percentile figures through their study on weight, height and BMI percentile figures of Turkish children 
at 6-18 years of age $(16,17)$. In our study the individuals have been determined whether they are thin, normal, overweight or obese.

SPSS (Statistical Package for Social Sciences) for Windows 13.0 software is used for data coding and statistical analyzes. Minimum, maximum, average, median, standard deviation are used in the analysis of quantitative data, and frequency distribution is used in the analysis of qualitative data. Multivariate logistic regression analysis was performed to identify the risk factors of obesity. Significance level was accepted as $\mathrm{p}<0.05$.

RESULTS:

A total of 621 primary school students including 320 students from public schools, 301 students from private schools in 7-15 age group are participated in our study. Students' 295 are $(47,5 \%)$ girls, 326 are $(52.5 \%)$ boys. When the mothers' education and professional statuses are observed; the results are; $38.5 \%(\mathrm{n}=239)$ primary school, $28.3 \% \quad(n=176)$ high school, $16.4 \% \quad(n=102)$ academy graduate, $79.9 \%(n=496)$ housewife. Of the fathers; $33.5 \% \quad(n=208)$ primary school, 32.0\% $(n=199)$ high school, $26.2 \%(n=163)$ academy graduate, $50.9 \%$ $(n=316)$ workers. Situations of mothervocational training and father-vocational education are statistically significant according to school $(\mathrm{p}<0,05)($ Table 1$)$.

Table 1. Socio-demographic results

\begin{tabular}{|c|c|c|c|c|c|c|c|c|}
\hline \multirow[b]{2}{*}{ Gender } & \multicolumn{2}{|c|}{ Private School } & \multicolumn{2}{|c|}{ Public School } & \multicolumn{2}{|c|}{ Toplam } & \multirow[t]{2}{*}{$\chi^{2}$} & \multirow[t]{2}{*}{$\mathbf{P}$} \\
\hline & $\mathrm{n}=\mathbf{3 0 1}$ & $\%$ & $n=320$ & $\%$ & $n=621$ & $\%$ & & \\
\hline Girls & 151 & 50,2 & 144 & 45,0 & 295 & 47,5 & 1,660 & 0,198 \\
\hline Boys & 150 & 49,8 & 176 & 55,0 & 326 & 52,5 & & \\
\hline $\begin{array}{c}\text { Educational Status of } \\
\text { Mothers }\end{array}$ & $n=301$ & $\%$ & $n=320$ & $\%$ & $n=621$ & $\%$ & $\chi^{2}$ & $\mathbf{P}$ \\
\hline Illiterate & 2 & 0,7 & 64 & 20,0 & 66 & 10,6 & 329,444 & $<0,0001$ \\
\hline Literate & 2 & 0,7 & 36 & 11,3 & 38 & 6,1 & & \\
\hline Primary school & 52 & 17,3 & 187 & 58,4 & 239 & 38,5 & & \\
\hline High School & 148 & 49,2 & 28 & 8,8 & 176 & 28,3 & & \\
\hline University & 97 & 32,2 & 5 & 1,6 & 102 & 16,4 & & \\
\hline Job of Mothers & $\mathrm{n}=\mathbf{3 0 1}$ & $\%$ & $n=320$ & $\%$ & $n=621$ & $\%$ & $\chi^{2}$ & $\mathbf{P}$ \\
\hline Housewife & 203 & 67,4 & 293 & 91,6 & 496 & 79,9 & 89,451 & $<0,0001$ \\
\hline Worker & 10 & 3,3 & 20 & 6,3 & 30 & 4,8 & & \\
\hline Officer & 25 & 8,3 & 1 & 0,3 & 26 & 4,2 & & \\
\hline Retired & 23 & 7,6 & 0 & 0,0 & 23 & 3,7 & & \\
\hline Others & 40 & 13,3 & 6 & 1,9 & 46 & 7,4 & & \\
\hline
\end{tabular}


Halime Pulat Demir, Kubilay Karşıdağ . Assessment of the nutritional status and the prevalence of obesity in the primary school children belong to different socio-economic status

\begin{tabular}{ccccccccc}
\hline $\begin{array}{c}\text { Educational Status of } \\
\text { Fathers }\end{array}$ & $\mathbf{n = 3 0 1}$ & $\mathbf{\%}$ & $\mathbf{n = 3 2 0}$ & $\mathbf{\%}$ & $\mathbf{n = 6 2 1}$ & $\mathbf{\%}$ & $\chi^{\mathbf{2}}$ & $\mathbf{P}$ \\
\hline Illiterate & 0 & 0,0 & 6 & 1,9 & 6 & 1,0 & 235,338 & $<\mathbf{0 , 0 0 0 1}$ \\
Literate & 1 & 0,3 & 44 & 13,8 & 45 & 7,2 & & \\
Primary school & 35 & 11,6 & 173 & 54,1 & 208 & 33,5 & & \\
High School & 125 & 41,5 & 74 & 23,1 & 199 & 32,0 & & \\
University & 140 & 46,5 & 23 & 7,2 & 163 & 26,2 & & \\
\hline Job of Fathers & $\mathbf{n}=\mathbf{3 0 1}$ & $\mathbf{\%}$ & $\mathbf{n}=\mathbf{3 2 0}$ & $\mathbf{\%}$ & $\mathbf{n}=\mathbf{6 2 1}$ & $\mathbf{\%}$ & $\chi^{\mathbf{2}}$ & $\mathbf{P}$ \\
\hline Self-employement & 180 & 59,8 & 46 & 14,4 & 226 & 36,4 & 141,002 & $<\mathbf{0 , 0 0 0 1}$ \\
Worker & 93 & 30,9 & 223 & 69,7 & 316 & 50,9 & & \\
Officer & 16 & 5,3 & 22 & 6,9 & 38 & 6,1 & & \\
Retired & 9 & 3,0 & 18 & 5,6 & 27 & 4,3 & & \\
Others & 3 & 1,0 & 11 & 3,4 & 14 & 2,3 & & \\
\hline
\end{tabular}

Of the students $79.9 \%(n=496)$ have lunch consumption and number of the regular breakfast, $86.5 \%(n=537)$ meals they have a day as per their have regular lunch, 96.9\% (602) have schools have a meaningful connection regular dinner (Table 2). Regular $(\mathrm{p}<0,05)$.

Table 2. Meal Consumption Status of Students

\begin{tabular}{|c|c|c|c|c|c|c|c|c|}
\hline \multirow[b]{2}{*}{ Number of Meals } & \multicolumn{2}{|c|}{ Private School } & \multicolumn{2}{|c|}{ Public School } & \multicolumn{2}{|l|}{ Total } & \multirow[b]{2}{*}{$\chi^{2}$} & \multirow[b]{2}{*}{$\mathbf{P}$} \\
\hline & $\mathbf{n}=301$ & $\%$ & $\mathbf{n}=\mathbf{3 2 0}$ & $\%$ & $n=621$ & $\%$ & & \\
\hline 1 meal & 1 & 0,3 & 3 & 0,9 & 4 & 0,6 & 35,939 & $<0,0001$ \\
\hline 2 meals & 19 & 6,3 & 35 & 10,9 & 54 & 8,7 & & \\
\hline 3 meals & 120 & 39,9 & 186 & 58,1 & 306 & 49,3 & & \\
\hline 4 meals & 132 & 43,9 & 80 & 25,0 & 212 & 34,1 & & \\
\hline 5 or more & 29 & 9,6 & 16 & 5,0 & 45 & 7,2 & & \\
\hline Regular Breakfast & $\mathrm{n}=\mathbf{3 0 1}$ & $\%$ & $\mathbf{n}=\mathbf{3 2 0}$ & $\%$ & $n=621$ & $\%$ & $\chi^{2}$ & $\mathbf{P}$ \\
\hline Yes & 238 & 79,1 & 258 & 80,6 & 496 & 79,9 & 0,233 & 0,629 \\
\hline No & 63 & 20,9 & 62 & 19,4 & 125 & 20,1 & & \\
\hline Regular Lunch & $\mathrm{n}=\mathbf{3 0 1}$ & $\%$ & $n=320$ & $\%$ & $n=621$ & $\%$ & $\chi^{2}$ & $\mathbf{P}$ \\
\hline Yes & 278 & 92,4 & 259 & 80,9 & 537 & 86,5 & 17,298 & $<0,0001$ \\
\hline No & 23 & 7,6 & 61 & 19,1 & 84 & 13,5 & & \\
\hline Regular Dinner & $\mathrm{n}=301$ & $\%$ & $n=320$ & $\%$ & $n=621$ & $\%$ & $\chi^{2}$ & $\mathbf{P}$ \\
\hline Yes & 292 & 97,0 & 310 & 96,9 & 602 & 96,9 & 0,010 & 0,922 \\
\hline No & 9 & 3,0 & 10 & 3,1 & 19 & 3,1 & & \\
\hline
\end{tabular}


It is found as $11.9 \%(74)$ of students are overweight, $11.8 \%$ (73) of students are obese. $15,3 \%$ of the students from private schools are overweight, $17,3 \%$ obese, as for the students from state school; $8,8 \%$ are overweight, $6,6 \%$ are obese. BMI distribution is statistically significant according to school $(\mathrm{p}<0,05)$. According to genders, there is no significant difference in the distribution of BMI ( $p>0,05)$. BMI distribution by age is statistically significant $(\mathrm{p}<0.05)$. Distribution of BMI classes is shown in table 3.

Table 3. The distribution of the BMI classes

\begin{tabular}{|c|c|c|c|c|c|c|c|c|c|c|c|c|}
\hline \multirow{3}{*}{ School } & \multicolumn{10}{|c|}{ BMI } & \multirow{3}{*}{$\chi^{2}$} & \multirow{3}{*}{$\mathbf{P}$} \\
\hline & \multicolumn{2}{|c|}{ Thin } & \multicolumn{2}{|c|}{ Normal } & \multicolumn{2}{|c|}{ Overweight } & \multicolumn{2}{|c|}{ Obese } & \multicolumn{2}{|c|}{ Total } & & \\
\hline & $\mathbf{n}$ & $\%$ & & $\%$ & $\mathbf{n}$ & $\%$ & $\mathbf{n}$ & $\%$ & $\mathbf{n}$ & $\%$ & & \\
\hline $\begin{array}{l}\text { Private } \\
\text { School }\end{array}$ & & 8,3 & 178 & 59,1 & 46 & 15,3 & 52 & 17,3 & 301 & 100 & 35,213 & $<0,0001$ \\
\hline $\begin{array}{l}\text { Public } \\
\text { School }\end{array}$ & 62 & 19,4 & 209 & 65,3 & 28 & 8,8 & 21 & 6,6 & 320 & 100 & & \\
\hline Gender & $\mathbf{n}$ & $\%$ & & $\%$ & $\mathbf{n}$ & $\%$ & $\mathbf{n}$ & $\%$ & $\mathbf{n}$ & $\%$ & $\chi^{2}$ & $\mathbf{P}$ \\
\hline Girls & 36 & 12,2 & 180 & 61,0 & 42 & 14,2 & 37 & 12,5 & 295 & 100 & 4,298 & 0,231 \\
\hline Boys & 51 & 15,6 & 207 & 63,5 & 32 & 9,8 & 36 & 11,0 & 326 & 100 & & \\
\hline Age & $\mathbf{n}$ & $\%$ & & $\%$ & $\mathbf{n}$ & $\%$ & $\mathbf{n}$ & $\%$ & $\mathbf{n}$ & $\%$ & $\chi^{2}$ & $\mathbf{P}$ \\
\hline 7 & 4 & 8,5 & 30 & 63,8 & 5 & 10,6 & 8 & 17,0 & 47 & 100 & 36,616 & 0,048 \\
\hline 8 & 4 & 13,3 & 18 & 60,0 & 4 & 13,3 & 4 & 13,3 & 30 & 100 & & \\
\hline 9 & 15 & 21,4 & 34 & 48,6 & 10 & 14,3 & 11 & 15,7 & 70 & 100 & & \\
\hline 10 & 8 & 8,7 & 59 & 64,1 & 15 & 16,3 & 10 & 10,9 & 92 & 100 & & \\
\hline 11 & 4 & 4,5 & 62 & 69,7 & 11 & 12,4 & 12 & 13,5 & 89 & 100 & & \\
\hline 12 & 12 & 11,1 & 73 & 67,6 & 14 & 13,0 & 9 & 8,3 & 108 & 100 & & \\
\hline 13 & 18 & 22,0 & 49 & 59,8 & 7 & 8,5 & 8 & 9,8 & 82 & 100 & & \\
\hline 14 & 16 & 18,2 & 55 & 62,5 & 7 & 8,0 & 10 & 11,4 & 88 & 100 & & \\
\hline 15 & 6 & 40,0 & 7 & 46,7 & 1 & 6,7 & 1 & 6,7 & 15 & 100 & & \\
\hline Total & 87 & 14,0 & 387 & 62,3 & 74 & 11,9 & 73 & 11,8 & 621 & 100 & & \\
\hline
\end{tabular}

It is found a statistically significant relationship between BMI and waist circumference, hip circumference, waist/hip ratio.A statistically meaningful correlation is found between hip and waist circumferences, waist circumference and waist/hip ratio; hip circumference and waist/hip ratio. Correlation coefficients and $\mathrm{p}$ values are given in Table 4. 
Halime Pulat Demir, Kubilay Karşıdağ . Assessment of the nutritional status and the prevalence of obesity in the primary school children belong to different socio-economic status

Table 4. The relationship between BMI and waist circumference, hip circumference and waist/hip ratio

\begin{tabular}{llllll}
\hline & & BMI & $\begin{array}{l}\text { Waist } \\
\text { Circumference }\end{array}$ & $\begin{array}{l}\text { Hip } \\
\text { Circumference }\end{array}$ & Waist/Hip Ratio \\
\hline BMI & $\mathbf{r}$ & 1 & 0,852 & 0,865 & $-0,131$ \\
& $\mathbf{p}$ & & $<0,001$ & $<0,001$ & 0,001 \\
\hline Waist & $\mathbf{r}$ & 0,852 & 1 & 0,848 & 0,151 \\
Circumference & $\mathbf{p}$ & $<0,001$ & & $<0,001$ & $<0,001$ \\
\hline Hip Circumference & $\mathbf{r}$ & 0,865 & 0,848 & 1 & $-0,384$ \\
& $\mathbf{p}$ & $<0,001$ & $<0,001$ & & $<0,001$ \\
\hline Waist/Hip Ratio & $\mathbf{r}$ & $-0,131$ & 0,151 & $-0,384$ & 1 \\
& $\mathbf{p}$ & 0,001 & $<0,001$ & $<0,001$ & \\
\hline
\end{tabular}

When we observe the risk factors for obesity, by multiple variable regression analysis; the independent variables included in the model such as; the number of individuals in the family, mother's profession, monthly total income, show no statistically difference $(p>0,05)$. Only the way they go to school is statistically different $(\mathrm{p}<0,05)$. Study has shown that going to the school by shuttle is found to increase the obesity risk by 2,783 times, and going to school by private car increases the obesity risk by 3,188 times. Data belonging to the Logistic regression is given in Table 5.

Table 5. Risk factors for Obesity

\begin{tabular}{c|l|l|l|l}
\hline \multicolumn{2}{c}{ OR } & 95\% Confidence Interval & $p$ \\
\hline \multicolumn{4}{c}{ Lower } & \\
\hline The way go to school & & & 5,141 & 0,001 \\
$\quad$ School bus & 2,783 & 1,507 & 6,449 & 0,001 \\
$\quad$ Private car & 3,188 & 1,576 & $0 p$ \\
\hline
\end{tabular}

\section{DISCUSSION}

In our country there is no study on frequency of children and adolescent obesity, however there are various local and regional studies performed in the past. In a study performed in Istanbul, Ankara and Izmir; 1044 adolescents of 12-13 years of age; $12 \%$ of the children are found to be slim , $12 \%$ overweight and $2 \%$ are found to be obese. Again in these three provinces, on another study on the same age group made on 1014 adolescents; obesity prevalence for boys is determined to be $15,1 \%$, as for the girls it is $13,3 \%$. Yeditepe University's study in upper socio-economical region; on 20 private nurseries, primary education schools and high schools, the results suggest that $16,7 \%$ of the girls, $25 \%$ of the boys were obese. Also, 34,4\% of the boys at 10-12 years of age, were under serious risk of obesity (18). Özumut's study in 2004 in Istanbul on adolescent children, for upper-socio-economic rank the frequency for incidence of over normal weight threshold is found to be $24,8 \%$ for girls, and $35,5 \%$ for boys(19). Öztora's study involving 299 students of a private primary education school in Istanbul; 26,7\% of the students were found to be overweight, 
$8,4 \%$ were found to be obese (7). In a study in 2011 in Kayseri; overweight students' prevalance is $12,4 \%$, obese students' prevalance is $6,5 \%$ (20). According to ?ava?han et.al. study, performed in 2014 in Ankara on 71 primary education school; $11,1 \%$ is overweight, $7,5 \%$ is obese $(21)$. Tola et.al.study in Isparta on schools grouped as per their socio-economical rank, consisting of 7 primary education school and high school, has shown that obesity frequence is $11,6 \%$, overweight incidences' frequency is $12,2 \%$ (22). In our study, similar to Tola et.al.study; $11,9 \%$ of the children were overweight, and $11,8 \%$ were obese.

It is reported that physical activity is reduced by $50 \%$ in adolescence,and the girls live more sedentarily than boys(23). NHANES III data indicates that in USA on 6-11 age group boys and girls without specifying the difference in gender, the obesity frequence is respectively $10,8 \%$ and $10,7 \%$. In the same study, in the $12-$ 17 years of age group; obesity rate is determined to be $12,8 \%$ among boys and $8,8 \%$ among girls and intersexual difference in overweight group has been observed(24). There was no significant difference in terms of obesity and gender in our study similarly. The reason to make the difference in obesity frequencies, can be the fact that today the hormonal changes normally accompanying menopause or pregnancy, and adding to the possibility of obesity do not occur anymore.

Pro Children study revealed that in 9 European countries among boys of 11 years of age the percentage of abovenormal weight incidences is $17 \%$, for girls it is $14 \%$ (25). Kutlu's study in Konya on primary education schools on girls and boys; most common incidence among 13 years of age is being slim, as for the 14 years of age they are obese (26). In our study, the BMI dispersion of the agebased student groups is found to be as follows; most common incidence for 10 years of age is overweight $(16,3 \%), 7$ years of age obesity prevalence is $(17,0 \%)$. The results are found statistically different $(\mathrm{p}<0.05)$. It found a statistically significant difference in terms of obesity in the age of 7,9 and 10 considering separately according to schools. Students in this age group in particular has seen more obesity compared to students in the state schools. While 8 students are obese in the 7 years of age group in the private school, there was no obese students in the same age group in the state school. The fact that the students of 7 years of age at private schools often have obesity; brings to mind the idea that the children start school with a weight above normal value.

The prevalence of obesity is increasing in school-age children because of the fact that Turkey is among the developing countries and socio-economic status rise in large metropolitan areas. The studies indicate that obesity is more common in lower socio-economic rank in developed countries, and it is more common in upper socio-economic rank in developing countries. (2). Özturk et.al. study finds that the prevelance of obesity among students from upper socio-economical is higher and this is statistically different $(p<0.05)(20)$. Similarly, our study has indicated that the students from private schools are overweight $(15,3 \%)$ and obesity prevalence $(17,3 \%)$ is more than those who are at state school (overweight: $8,8 \%$, obesity: $6,6 \%$ ). In the school from upper socio-economic rank, obesity prevalence is higher and this is an indicator that external factors are more 
Halime Pulat Demir, Kubilay Karşıdağ . Assessment of the nutritional status and the prevalence of obesity in the primary school children belong to different socio-economic status

effective than genetical factors in our society; ease of access to food resources, malnutrition habits accompanied by sedimentary lifestyle are main points of interest in this context and bring into the agenda the necessity of taking required precautions in this context. 2013 Turkey Population and Health Research(TNSA2013) results suggest that; poor nutrition is a problem of lower socio-economic rank, and being overweight/fat is a problem of higher socio-economic rank (27).

According to a study performed on Dutch children, BMI-SDS and waistSDS have high correlation, BMI-SDS and waist/hip-SDS have low correlation therefore waist circumference is thought to be an indicator which can be used in determining abdominal fattening(28). In Turgut's study in Erzurum on school kids of 6-15 years of age; waist circumference, hip circumference and obesity are found to have a relation. The best correlation with BMI were found with waist circumference in the same study (29). In our study, statistically significant differences were detected between obese group, overweight group, normal and slim groups in waist and hip circumference measurement. The values that we found are positively correlated with BMI. It was the hip circumference measurements showing the strongest correlation with BMI $(\mathrm{r}=0,865)$. When evaluating obesity among children; we believe that it is important to take into consideration the measurements taken around the hip and waist, along with the BMI, especially in regard to abdominal fattening.

The educational level of parents and the careers of them are some of the most important factors in determining the level of income. In a study conducted in Kahramanmaras, overweight and obesity is significantly associated with education level of the parents (30).

In the study of the S?zek and et.al. (31) obesity rate was found higher in the children of working parents. In our study, we found difference between obesity and mother's profession/education, father's profession/education. The reason of this is that; when the level of education in our country increases, income levels are also increasing. This causes increasing of carbohydrate, fat and fast food/beverage consumption. Working mothers' tending to more frozen and packaged foods increases the risk of obesity for children.

The individual have to take daily energy and nutrients in every meal sufficiently and evenly. The study revealed that $49,3 \%$ of the children eat 3 meals and 34,1\% eat 4 meals in a day. No correlation was found between obesity and the number of meals. Significant differences were found in terms of the number of meals according to the schools. $43,9 \%$ of the students from private schools eat 4 meals in a day, as for the students from state school; 58,1\% eat 3 meals in a day. A higher rate of obesity in private schools reveals that private school students consumed both their main meal regularly and highcalorie food outside the main meals.

A study in Istanbul has shown that 8.6\% of the students walk to school and it does not effect the risk of obesity (7). In a study performed in Ankara, among all groups the percentage of the students who walk to school was found to be $60.8 \%$, there was no differences between the means of going the school and BMI (32). In our study, considering the risk factors for obesity with logistic regression analysis; just the way of going to the school is statistically significant $(p<0.05)$. Going to the school by service(versus walking to school) increases the obesity risk by 2.783 
times and going to the school by private car(versus walking to school) increases the risk of 3,188 times. It can be said that going to school by car or service is more effective compared to other factors about getting more obesity in private schools.

As a result of our study, it is seen that especially sedentary lifestyle is effective in the childhood obesity. Obesity is seen more often in the children of parents who have higher socio-economic statue. Obesity is more found in the children of parents who have higher education levels and working mothers.

To prevent childhood obesity before it occurs, should be an important goal of health care. Nutrition education should be given at regular intervals to children in schools, obesity screening should be done, families should be informed for students who are seen as risky and necessary precautions are taken. Besides BMI, evaluation of measurement of waist circumference may be helpful for the early identification of Students who are at risk for abdominal obesity. Areas and time that will provide to increase the physical activity of children should be created in schools. It is necessary to take precautions at local, national and international level against obesity.

\section{References}

[1] Baysal A. Beslenme. Ankara: Hatiboğlu Yayıncılık; 2009.

[2] Baysal A, Aksoy M, Bozkurt N. Diyet El Kitabı. Ankara: Hatiboğlu Yayıncılık; 2008.

[3] Akbulut GÇ, Özmen MM, Besler HT. Obezite. Tübitak Dergisi 2007; Mart sayısı eki.

[4] Baysal A, Baş M, editörler. Yetişkinlerde Ağırlık Yönetimi, Ankara: Ekspres Baskı; 2008.

[5] Sencer E, Orhan Y. Beslenme. İstanbul: İstanbul Medikal Yayıncılık Ltd. Şti; 2005.

[6] Güler Y., Gönener H.D., Altay B., GÖNENER A. (2009) Adölesanlarda obezite ve hemsirelik bakımı. Fırat Saglık Hizmetleri Dergisi, Cilt 4, Say1:10, s:165.)

[7] Öztora S. İlköğretim çağındaki çocuklarda obezite prevalansının belirlenmesi ve risk faktörlerinin araştırılması. Uzmanlık Tezi, 2005.

[8] Atar A. (2005) Obezlerde Plazma Lipid Düzeyleri İle Antropometrik Ölçümler Arasındaki İlişkinin İncelenmesi. Taksim Eğitim ve Araştırma Hastanesi Aile Hekimliği Koordinatörlüğü Aile Hekimliği Uzmanlık Tezi İstanbul. s:6.

[9] Şimşek F., Ulukol B., Berberoğlu M., Gülnar S.B., Adıyaman P., Öcal G. (2005) Ankara'da bir ilköğretim okulu ve lisede obezite sıklığı. Ankara Üniversitesi Tıp Fakültesi Mecmuası. 58:163-166.

[10] Günöz H. Şişmanlık. In: Neyzi O, Ertuğrul T.(eds), Pediatri 3. Baskı, İstanbul: Nobel Tıp Kitabevi, 2002.

[11] British Medical Association Report. Preventing Childhood Obesity, London; 2005. www.bma.org.uk (Erişim tarihi: Aralık 2010)

[12] Ulusal Gıda Ve Beslenme Stratejisi Çalışma Grubu Raporu (Ulusal Gıda Ve Eylem Planı I. Aşama Çalışması Eki) Yayın No DPT : 2670, Mart 2003.

[13] Korkmaz A, Topal T. Modern yaşam tarzı ve yeni hastalıklar: Metabolik Sendrom örneği. TSK Koruyucu Hekimlik Bülteni 2006: 5 (4): 307-316

[14] Hatipoğlu N, Öztürk A, Mazicioğlu M.M, Kurtoğlu S, Seyhan S, Lokoğlu F. Waist circumference percentiles for 7- to 17year-old Turkish children and adolescents. Eur J Pediatr 2008; 167:383-389.

[15] Lissau I, Overpeck MD, Ruan WJ, et al. Body mass index and overweight in adolescents in 13 European countries, Israel and the United States. Arch Pediatr Adolesc Med 2004;158: 27-33.

[16] Bundak R, , Furman A, Gunoz H, Darendeliler F, Bas F, Neyzi O.Body mass index references for Turkish children. Acta Pcediatrica 2006; 95: 194-198.

[17] Neyzi O, Günöz H, Furman A, Bundak R, Gökçay G, Darendeliler F, Baş F. Türk çocuklarında vücut ağırlığı, boy uzunluğu, baş çevresi ve vücut kitle indeksi referans değerleri. Çocuk Sağlığ ve Hastalıkları Dergisi 2008; 51: 1-14.

[18] Türkiye'de obezitenin görülme sıklığı. T.C. Sağlık Bakanlığı Temel Sağlık Hizmetler Genel Müdürlüğü. (internette) 2011, Erişim 10.01.2011 http://www.beslenme.saglik.gov.tr/index.php?pid=40.

[19] Özümüt SH. Adölesanlarda Obezite Prevalansının Belirlenmesi ve Risk Faktörlerinin Araştırılması. Yayınlanmamış Uzmanlık Tezi. SSK Göztepe Eğitim Hastanesi, Pediatri Kliniği, İstanbul: 2004.

[20] Öztürk A, Aktürk S. İlköğretim öğrencilerinde obezite prevalansı ve ilişkili risk faktörleri. TAF Prev Med Bull 2011; 10(1): 53-60. 
Halime Pulat Demir, Kubilay Karşıdağ . Assessment of the nutritional status and the prevalence of obesity in the primary school children belong to different socio-economic status

[21] Şavaşhan Ç, Sarı O, Aydoğan Ü, Erdal M. İlkokul çağındaki çocuklarda obezite görülme sıklığı ve risk faktörleri. Türk Aile Hek Derg 2015; 19 (1): 2-9.

[22] Tola ve ark. Isparta'daki çocuk ve adölesanlarda obezite sıklı̆ğ ve obeziteyi etkileyen faktörler. Çocuk Dergisi 2007; 7(2):100-104.

[23] Goran MI, Gower Ba, Nagy TR, Johnson RK. Developmental changes in energy expenditure and physical activity in children: evidence for a decline in physical activity in girls before puberty. Pediatrics 1998; 101: 887-91.

[24] Styne DM. Childhood and adolescent obesity, prevelance and significance. Pediatr Clin North Am 2001;48:823-854.

[25] Yngve A, Wolf A, Poortvliet E, et all. Fruit and vegetable intake in a sample of 11 year-old children in 9 European countries: The pro children cross-sectional survey. Ann Nutr Metab. 2005; 49: 236-245.

[26] Kutlu R, Çivi S, Köroğlu E. Fatih Sultan Mehmet İlköğretim Okulu öğrencilerinin antropometrik ölçümlerinin değerlendirilmesi. Med Bull 2008;7(3):205-212.

[27] Türkiye Nüfus ve Sağlık Araştırması 2013. Hacettepe Üniversitesi Nüfus Etütleri Enstitüsü Ankara. (internette) 2014 , Erişim 30.08.2016 http://www.hips.hacettepe.edu.tr/tnsa2013/rapor/TNSA_2013_ana_rapor.pdf

[28] Fredriks MA, Buuren SV, Fekkes M. Are age references for waist circumference and waist-hip ratio in Dutch children useful in clinical practice? Eur J Pediatr 2005;164: 216-222.

[29] Turgut A. Erzurum'da yaşayan $6-15$ yaş grubu okul çocuklarında obezite prevalansı ve risk faktörleri. Atatürk Üniversitesi. Tıp Fakültesi. Çocuk Sağlığı ve Hastalıkları AD, Uzmanlık Tezi, Erzurum 2008.

[30] Çıtırık D. Kahramanmaraş İl Merkezinde İlköğretim Öğrencilerinde Obezite Prevalansı. Tıpta Uzmanlık Tezi. Kahramanmaraş: Kahramanmaraş Sütçü İmam Üniversitesi; 2008.

[31] Süzek H, Arı Z, Uyanık B. Muğla' da yaşayan 6-15 yaş okul çocuklarında kilo fazlalığı ve obezite prevalansı. Türk Biyokimya Dergisi 2005; 30: 290-295.

[32] Bilici Aköz E. 6-16 Yaş Okula Giden Çocuklarda Beslenme Alışkanlıklarının Büyüme Gelişme ve Obezite Üzerine Etkileri. Tıpta Uzmanlık Tezi. Ankara T.C.Sağlık Bakanlığı Ankara Eğitim Ve Araştırma Hastanesi; 2006. 